\title{
Mystical Death in the Spirituality of Saint Teresa of Ávila
}

\section{Slavomír Gálik ${ }^{1}$ • Sabína Gáliková Tolnaiová ${ }^{1}$ • Arkadiusz Modrzejewski ${ }^{2}$}

Published online: 20 May 2020

(C) The Author(s) 2020

\begin{abstract}
In this article, the authors study the phenomenon of mystical death in the spirituality of Saint Teresa of Ávila. They first explain the phenomenon of mystical death in the history of Christian spirituality. The authors note that the history of this phenomenon goes as far back as the New Testament, where it can be found in the texts by St. Paul and St. John, but it was first formulated explicitly by an unknown author much later - in the seventeenth century. Mystical death is a concept used to explain mystics' experience of transformation from selfcenteredness to other-centeredness. The authors want to use this concept to open up a further interpretation of Teresa of Ávila's work, it provides a key for unlocking a major theme of her work. In the mysticism of Saint Teresa of Ávila, the authors investigate this phenomenon in two of her books: The Interior Castle or The Mansions and The Life of Teresa of Jesus. Firstly, this phenomenon is in her description of the fifth mansion of The Interior Castle or The Mansions in the symbolism of the transformation of a caterpillar into a butterfly, conditioned by ascending of internal energies. Secondly, they can trace the phenomenon of mystical death in her work The Life of Teresa of Jesus, especially in her explanation of her near-death experience. According to the authors, the phenomenon of mystical death in the mysticism of Teresa of Ávila constitutes a condition for higher spiritual states, especially the state of mystical unity (lat. unio). Finally, the authors outline that the phenomenon of mystical death in the spirituality of Teresa of Ávila is similar to mysticism in Eastern spiritual traditions. They discuss the importance of revealing these similarities for a better understanding of the human being and hir further spiritual development.
\end{abstract}

Keywords Mysticism · Mystical death $\cdot$ Mansions in Teresa’s Interior Castle

\section{Introduction}

The first and basic question is: What is mysticism? This question implies another, even more important one: Does mysticism speak about something real or not? In

Slavomír Gálik

s_galik@yahoo.com

Extended author information available on the last page of the article 
this article, we start with the assumption that great mystics across religions did not intend to lie and, depending on the era, culture, and language, they wanted to express as precisely as possible what they experienced and learned. This is the reason why we believe that mysticism hides the greatest deal of truth about human existence and, when interpreted correctly, we can understand this message. Mysticism is generally defined as consciousness of being (spirit) that can only be reached by personal transformation. Also Davy (2000, p. 8) links mysticism to personal transformation when she says: 'a mystic is a person who has reached the spirit. Spirit is a revolutionist; every advanced spirit mightily outgrows the old bounds ...' Being is what consciousness aims at, but mystic consciousness is also a way of aiming that ascends through concrete steps. This mystical ascent was known in Christian mysticism from the Middle Ages, and its roots are found in the mystical ladder of patriarch Jacob. Many mystic authors spoke about a journey, or ascent to God, among them is for example Bonaventure in his work Journey of the Soul into God. Ascent, or gradation, can also be found in the classic three-phase or triad understanding of mystics by Pseudo-Dionysius the Areopagite-purification, illumination, unification (purificatio, illuminatio, unio in Latin).

Bernard McGinn (S. Zarrabi-Zadeh 2008, p. 82), one of the greatest contemporary experts on Christian mysticism, notes that 'goal of mysticism may be conceived of as a special kind of God-human encounter.... immediate or direct presence of God.' This approach to mysticism is also good for clarification of Teresa of Ávila's mysticism. She speaks of two loving persons (Teresa and Jesus) who are closely related to each other. Also Sudbrack (1995, p. 47) speaks similarly when he describes Teresa's mysticism as friendship mysticism. ${ }^{1}$

The second question is: What is mystical death? This notion is connected with the archetypal matrix life-death-rebirth (Eliade 1997, p. 216). In Christian spiritual tradition, the term 'mystical death' relates to the death and resurrection of Christ and for Christian-following the Christ's death and resurrection. Mystical death is a one important part of the mystic way and also the required condition to reach unity with God.

In the spirituality of Teresa, we encounter a complex form of mysticism. In the fifth mansion, described in her Interior Castle is a way of ascent involving self-transformation, and the seventh mansion describes the goal of mysticismunity with God. In this paper, we would like to examine the mysticism of St.

\footnotetext{
${ }^{1}$ These authors see mysticism as a spiritual core of religions. The primary role of religions is to deal with the problems of death through an offer of some kind of immortality. Mysticism, or the greatest level of spirituality in every religion, deals with this problem through a direct experience of going beyond the physical and cognitive limits of the human body and consequent insight into transcendence. This can happen with the help of the so-called subtle energies that act as a bridge between the mind and body. If these subtle energies expand from within the human's body, for example, through fully developed chakras (including Sahasrara), then also human's consciousness expands outside of the body. This may be experienced as a state of dying or death, followed by transcendence. However, these authors do not claim that mystical death may only be univocal and with only one possible scenario, but that it will always show signs of radical transformation and experience of transcendence. On the other hand, it is difficult to describe transcendence adequately, as the description depends on the language, culture, and religion. Teresa of Ávila describes it as unity with God, Buddhism sees it as nirvana, while Yoga calls it Samadhi. We prefer the term of 'living emptiness' - it indicates both personal and impersonal dimensions.
} 
Teresa of Ávila in general, and especially, the phenomenon of mystical death. How to approach and understand the mysticism of St. Teresa of Ávila? We know both her vision of mystical ascent in her Interior Castle and the interpretations of numerous philosophers and theologians. Of course, we also have our own interpretation of mystical death of St. Teresa of Ávila. We have several hermeneutic interpretations and they can be further extended. We will need to find a certain harmony among them to get a coherent and meaningful summary. Such are some of the problems and questions we raise in the very beginning of our exploration, but also present a challenge to perform as detailed examination of this unique phenomenon as possible, especially since it is in St. Teresa of Ávila, who was one of the greatest Western Christian mystics, and given the title 'Doctor of the Church.' We can guess that the phenomenon can probably teach us most about humans and being; mysticism surpasses common understanding of the world, provides insight into being, and is also an intuitive view into truth. It is for these reasons that we consider dealing with mysticism extremely important. It provides implicit answers to vital philosophical questions about life.

\section{About the Phenomenon of Mystical Death}

The term mystical death relates to the well-known matrix that is often found in religions - death and resurrection. According to Mircea Eliade, this matrix is widespread across religions because it represents a vital condition for opening to a new, spiritual, and sacral dimension and is perhaps even a key to understanding all religions (1997, p. 216). However, since this matrix can exist in a variety of meanings in these religions, we are primarily interested in how the Christian religion understands it.

In Christian spirituality, the term 'mystical death' relates to the death and resurrection of Christ. Since it is generally true that members of all religions follow their founders, it is also true for the Christian religion, where they follow Christ's death and resurrection. According to Paul Ricoeur, the apostle Paul transferred kerygma (proclamation of the gospel, death, and Christ's resurrection) to the existential situation of an old nature's death and a new birth. Ricoeur (1980, p. 46), for example, says this: 'Saint Paul creates this second modality of Christian hermeneutics when he invites the hearer of the word to decipher the movement of his own existence in the light of the Passion and Resurrection of Christ. Hence, the death of the old man and the birth of the new creature are understood under the sign of the Cross and the Paschal victory. But their hermeneutic relation has double meaning. Death and resurrection receive a new interpretation through the detour of this exegesis of human existence.' The Apostle Paul emphasizes it several times and in various letters. For example, in his letter to the Romans: 'Therefore we are buried with him by baptism into death: that like as Christ was raised up from the dead by the glory of the Father, even so we also should walk in newness of life. ... Because we know our old human was crucified along with him to have the sinful body destroyed, to stop being slave to sin.' (Rom 6, 4-6). In his letter to the Ephesians, he further analyzes the new existential situation of the Christians: 'You were taught to put 
away your former way of life, your old self, corrupted and deluded by its lusts, and to be renewed in the spirit of your minds, and to clothe yourselves with the new self, created according to the likeness of God in true righteousness and holiness.' (Eph 4, 22-24).

Paul's interpretation of Christ's death and resurrection set a firm foundation for both Christian mysticism and an understanding of the phenomenon of 'mystical death.' ${ }^{2}$ His interpretation is also supported by Jesus' speaking to Nicodemus about being reborn of water and the Spirit, which anticipates the death of the previous way of life (John 3, 3-7).

For a long time, there was no such term as 'mystical death' in Christian mysticism, even though it was implicitly there. For example, in the usual classification of mysticism by Pseudo-Dionysius the Areopagite - purification (lat. purificatio), illumination (lat. illuminatio), unification (lat. unio)—we may, in the purification phase, presume purging from all human desires that leads to delivering oneself to God (Larkin 1967, p. 2). The mystical phase of purification could be compared to Paul's 'surrender' of the old sinful man. We assume that at the end of this phase, there is a deep transformation of consciousness (metanoia -in Greek), which we could also interpret as mystical death.

In Christianity in the early modern period, there is an explicit idea of mystical death in the Treatise on Mystical Death that dates back to the sixteenth or seventeenth century and is wrongly supposed to be written by St. Paul of the Cross (Bialas 1990, p. 209). The unknown author speaks of mystical death (1-5): 'My Jesus, I must die and obey! You ask too much of me in one thing, because You want me to die with You on the Cross. A mystical death, a death however sweet, it's too hard for me because I must undergo a thousand deaths before dying! ... I will die completely to myself and live for God alone. I will certainly die for God, because I cannot live without God. Oh, what a life! Oh, what a death! I will live, but like a dead person. With such a thought I shall spend my life by living a continual death. ... I will ponder this strong maxim of the spirit of mystical death in the three vows of poverty, chastity and obedience. ... I will be the poorest, like a dead person. In so far as possible, I will not keep anything from myself. My sole thought will be that I must possess nothing, and that everything is superfluous as in the case of a dead person (Treatise on Mystical Death n. d.).'

\footnotetext{
${ }^{2}$ We think that Paul's concept of 'death of the old man and rebirth of the new man' was greatly influenced by his experience of conversion on the journey to Damascus. In the Acts of the Apostles (Acts 9: 3-9), it is written: 'As he was on the way there and approaching the city of Damascus, a light from heaven suddenly shone around him. He fell to the ground and heard a voice calling to him, "Saul, Saul, why do you persecute me?" He asked, "Who are you, lord?" and the voice answered, "I am Jesus, whom you are persecuting. But get up now, and go to the city. There you will be told what you are to do." His companions stood petrified, for they heard the voice but saw no one. Saul rose to his feet, but when he opened his eyes he could not see, and they had to take him by the hand and lead him to Damascus. For three days he was blind, and neither ate nor drank.' And also, his vision that he describes in his letter to the Corinthians (2 Cor 12, 2-4): 'I know a man in Christ who fourteen years ago was caught up to the third heaven. Whether it was in the body or out of the body I do not know - God knows. And I know that this man-whether in the body or apart from the body I do not know, but God knows - was caught up to paradise and heard inexpressible things, things that no one is permitted to tell.' We suppose this experience, especially his turn on the journey to Damascus, could be characterized also as mystical death, which transformed his personality. We also think that this experience significantly influenced his future theological concepts, particularly the concept of the death of the old man and rebirth of the new man.
} 
The unknown author writes about the phenomenon of mystical death in several ways. On the one hand, he distinguishes between mystical death and normal death. On the other hand, however, he also draws our attention to similarities. Mystical death is 'crucifying' of all the desires, likings, and self-love; it is a complete surrender to Christ. The author even speaks about poverty, nothingness in respect to the body and thinking, which evokes the language of Meister Eckhart or John of the Cross. Meister Eckhart (Wehr 2010, p. 68) in his sermon On Separation says: 'When I am to preach, I always speak of separation, that man needs to jettison himself and everything.' John of the Cross (1952, p. 188) too assumes 'nothing' when he speaks about two nights (senses and spirit) and total emptying of the soul: 'Of all these forms and kinds of knowledge the soul must strip and void itself, ... it remains without form and without figure, its imagination being lost and itself being absorbed in a supreme good, and in a great oblivion, remembering nothing. For that Divine union voids its fancy and sweeps it clean of all forms and kinds of knowledge and raises it to the supernatural.' Freeing oneself from all desires and tastes, reaching the state of complete 'purity of the soul', equals mystical death, which is a condition for unity with God since, nothing as restricted $(\mathrm{Me})$ can be united with the almighty (God).

How could we explain the phenomenon of mystical death in the perspective of modern approaches? We believe that one of the possible interpretation frames could be set in Jung's depth psychology. Carl Gustav Jung distinguishes between the empirical Me and temperamental Me-Self. The empirical Me is, he believes, formed during human ontogenesis. Yet, this 'me' is not an independent ontological substance but is dependent on the Self, which Jung (Stevens 1994, p. 64) interprets as a God-image in us. Jung believes the need to overcome ego is also indicated naturally-concretely in the second phase of life-which he sees as preparation for death and which should become a necessary part of life. He sees the end of a specific psychological and physical life in the phase of preparation for death and in death itself, but he also suggests the possibility of an integration of consciousness with the very basic Me-Self, thus achieving the final purpose of it all-opus. However, we must say that Jung did not think this was achievable. He thought of it as an ideal situation that we may only touch but not reach (Stevens 1994, p. 86). ${ }^{3}$ Nevertheless, this process is very obvious and radical in the mystics, because while still alive and traveling through the 'hell of unconsciousness', the mind (in this context seen as transitive and capable of freeing from Me (Gálik and Cenká 2013, 9: 234; Gálik and Gáliková Tolnaiová 2015a, 6: 10) of a mystic finally finds a unity with the very basic structure-God.

Mystical death is then 'death' or the act of detaching from the empirical Me, with its tastes and, desires, leaving empirical Me completely empty. Thus, human consciousness is freed and identified with the deeper Base, the very Self, or let us say-with God - nothing limited 'me' can reach unlimited God. After mystical death, the consciousness still keeps its bond with the body, or the temporary created 'me,' but without

\footnotetext{
3 Jung's concept of Self (when consciousness (me) merges with Self then the human's self-realizationopus - begins) is often criticized by theologists because it highlights the intramental rather than transcendent experience. Orientation towards intramental experience could be explained by Jung's psychological specialization and thinking that was influenced by German philosophy (Kant's transcendent and empirical me, Fichte's philosophy, and similar).
} 
the element of dependence since such structures are conquered and a higher spiritual position is reached.

We can use this understanding of the phenomenon of mystical death in the mysticism of St. Teresa of Ávila, symbolically expressed from a caterpillar into a white butterfly in the Fifth Mansion of The Interior Castle. ${ }^{4}$

\section{Several Methodological Remarks About the Mysticism of St. Teresa of Ávila}

As we mentioned in the 'Introduction,' when we explore the mysticism of St. Teresa of Ávila, it is important to keep in mind several possible approaches that carry certain risks of misinterpretation. First of all is her autobiography named The Life of Teresa of Jesus. She wrote this book in 1562, 12 years before The Interior Castle or The Mansions and 17 years before her death. In The Interior Castle or The Mansions, her ideas of spiritual growth are more complex and synthetic. Therefore, we should understand her autobiography 'through' The Interior Castle or The Mansions. In her autobiography, she speaks about two illnesses that may have affected her further spiritual progress. The first disease started while she was staying in the Augustinian Convent, where she went when she was 16. The second disease started when she was 20 and went to the Carmelite Convent in Ávila. This disease worsened so much that in the end she fainted and was unconscious for 4 days. Everybody thought she would die and they even had her grave prepared, but she woke up and said she had visited heaven. Can this disease, together with her spiritual experience, be described as a mystical death? Furthermore, was it a once-in-a-lifetime experience, or were there multiple occurrences?

Secondly, is her description of ascending the mystical road in her The Interior Castle or The Mansions. In the fifth mansion, she speaks of a simple mystical connection, with preceding inner transformation. She describes it allegorically as a caterpillar turning into a butterfly. A caterpillar, just like an old human, fades and a butterfly is born. It represents a new spiritual existence of human beings.

\footnotetext{
${ }^{4}$ In the history of Christian mysticism, we can find various descriptions and concepts of mystical death that depend greatly on language and era, but also sex. For example, in male mysticism, unlike the one of Teresa, to unify with God, man one must empty his mind and will. In Christianity of Middle Ages, Pseudo-Dionysius explains that a man must purify himself from everything and separate himself from everything (including ideas, words, and thinking) in order to be able to enter the 'dark cloud of God's mystery' (Sudbrack 1995, p. 25). Meister Eckhart says: 'When I preach, then I always talk about separation, about the need of man to get rid of himself and get rid of everything...' (Wehr 1999, p. 68). In the Medieval Christianity, John of the Cross speaks of the power of night and spirit - these are important for reaching unity with God. F. Ruiz Salvador interprets John's dark night as a 'unique experience of emptiness, because for reaching supernatural transformation, everything that belongs to human nature must be suppressed ... The desired goal that the night guides towards is a new man, merged with God in all his nature.' (Jan od Křžže 1995, p. 27). After the dark night, which means a radical transformation similar to mystical death, it is a 'vital flame of love' that dominates in John's mysticism; this flame is similar also to Teresa's mysticism of prayer levels with description of 'streams of milk' or 'brilliant light streams.' Jan od Křriže (1995, p. 144) for instance says: 'a helping power will miraculously grow ... in lively flames of God's love.' He mentions David's psalm $(39,3)$ : 'my heart grew hot within me. While I meditated, the fire burned; then I spoke with my tongue.' We do not understand John's descriptions to be just metaphorical; clearly he must be referring to subtle energies.
} 
The archaic picture of the transformation of a caterpillar into a butterfly could match our explored phenomenon of mystical death. The question is how to see this picture in terms of the life of Teresa.

Another thing that we need to keep in mind when we examine the mysticism of St. Teresa of Ávila is the period and geographic location she lived in, which is the sixteenth century in Spain. The spiritual atmosphere in Spain was very religious and mainly Catholic. The Reformation was going on, taking place in German countries, and St. Teresa of Ávila believed that the Lutherans would be damned. Moreover, people believed in Satan being very strong in his influence on people, especially women. The institution of the inquisition that detected and punished the heretics and those who disobeyed the Church was, in that time, at the peak of its strength and activity. It was normal to have witches burned at the stake, which, it seems, St. Teresa of Ávila did not approve of, even though she did believe in the possibility of being possessed by the Devil. Teresa herself was under the control of the inquisition and her scripts were scrutinized. However, her submission was so great that she could avow her mistake or amend and explain it so that it was in even better accord with teachings of the Church. However, it seems there were very few occasions like this. To paint an even better picture of the period, we need to add that the Moors (Muslims in Portugal), and even more so the Native Americans in the New World, were supposed to be pagans or simply bad people who needed to be taught the correct religion. For example, when Teresa was 7 years old, she joined her brother and went to meet Moors to become God's martyrs. Her older brothers went to the New World, where they doubtlessly fought the Native Americans too. One of her brothers later offered her the money that he had got in Peru. These are the events that depict the period, which needs to be interpreted from this standpoint, and not from our current position.

We have further interpretations of the mysticism of St. Teresa of Ávila by her biographers, writers, and those who somehow dealt with her mysticism. There is a big difference in the approach of the members of various confessions and religions and, of course, atheists. Speaking of the last category, we can speak of doctor Varela, who diagnosed Teresa's disease as the so-called Malta fever, brucellosis - which scars the heart (Sudbrack 1998, p. 34). This is how he tried to explain the mystical piercing she speaks about in her biography.

All these approaches include the hermeneutic method, the art of interpreting textsin this case texts written by St. Teresa of Ávila, dating back to the sixteenth century.

\section{Comparison of the Chakra System in Various Mystical Traditions}

Comparison is one of the basic tools of process of learning in humans. Without comparison, as Antalík (2005, p. 101) says, there is no knowledge. 'Comparison is not purely classification, it is especially a tool for understanding...' In this approach, we can relate also to various religions and especially to various mystical or spiritual traditions. In these traditions, we can find and compare various symbols, for example, fire, water, and whatever else. There are quite a lot of such image expressions of symbols, but many of them would be very 
difficult to understand without a thorough study in the given field. Despite this, there are also many symbols that are quite clear, because they are directly linked to the human body. In our case, it is the system of energy centers, the so-called chakras. We find the chakra system mainly in Hinduism, especially in Yoga, but also in other religions. The thing that all of the image-based expressions of chakras share is that they are linked to a certain point in the body and more generally also with descriptions of spiritual experience. We therefore think that the so-called chakra system of man could be an important starting point to study and especially to compare various mystical or spiritual traditions.

Etymology of the word 'chakra' comes from Sanskrit and means circle or wheel. Kumar and Larsen Kumar (2006, pp. 239-240) claim that 'chakras are energy whirls that correspond with certain nervous plexus. Before kundalini is awakened, chakras only have limited energy resources, similar to batteries. Chakras develop in concrete phases of development and represent milestones on the road of evolution.' The authors speak about 7 individual types of chakras: (1) Muladhara chakra, which lies below Kundalini chakra; (2) Svadhisthana chakra, placed at the spine above genitals; (3) Manipura chakra, placed around the solar plexus; (4) Anahata chakra, placed close to the spine in the heart area; (5) Vishuddhi chakra, placed near the throat in the spinal column, (6) Ajna chakra, placed in the middle of the brain; (7) Sahasrara chakra, placed above the crown of the head.

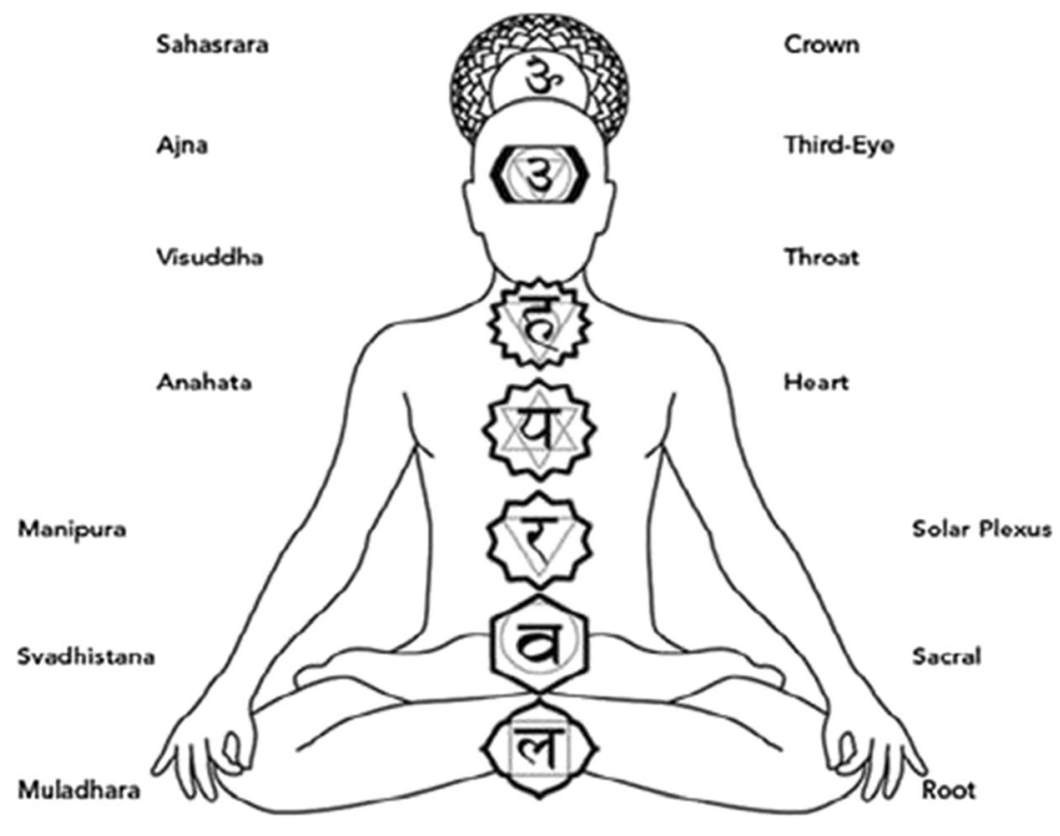

The seven major chakras in the body.

The most detailed teaching about chakras and kundalini can be found in Yoga, specifically in Hatha Yoga. Furthermore, this yoga terminology is universally known, so we use it also to describe other similar phenomena in other mystical traditions. 
Zen-Buddhist Jiyu-Kennett describes kundalini energy and chakras in a great detail. She (Jiyu-Kennett 1997, pp. 67-144) practiced Zen-Buddhist meditation technique and was gradually activating these energies and chakras until they were fully awakened. She took notes and drew pictures of the progress-her descriptions show that this awakening of energies was also experienced by other monks that practiced meditation. We know about her private - or subjective - experiences that were linked with her life, Buddhism, and also the Christian religion, and we also know about her objective observations of activating energy in the case of both the monks and also herself. Reading from her drawings, we may say that awakening chakra energies can expand our consciousness, but also free it from the body. When she was activating the 6th chakra, Jiyu-Kennet freed her mind from her body; we can call this 'mystical death'. She (Jiyu-Kennett 1997, p. 76) described the phenomenon of mystical death in this picture:

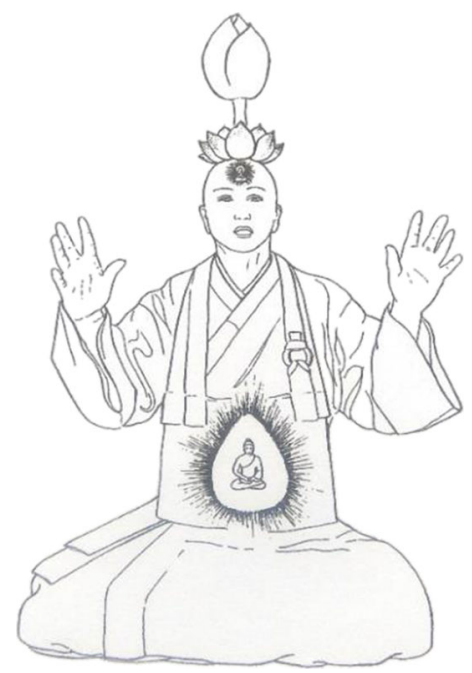

Mystical death of Jiyu-Kennett. During the opening of the 'third eye' for awhile she died

This kundalini and chakras seem to be a requirement for deeper mystical experiences, especially transcendence of mind, also known as mystical death. Jiddu Krishnamurti (Krišnamurti and Bohm 1992, p. 93) in an interview with D. Bohm also pointed out that the brain has to be in a state of high energy; thus, the mind is triggered and can achieve higher degrees of meditation.

After experiencing mystical death, Jiyu-Kennett used Buddhist meditation to awaken her chakra energies and free the mind. It is interesting here to compare, once again, JiyuKennett's internal (or subjective) experiences and her more - or less - objective drawings of the awakening energies. It seems that her mind started to free itself rapidly from the nervous system. Memories (biographical or non-biographical) were not hidden behind the sensory-motor of the nervous system but bare, unbound, in a hyperspace of the mind. When chakra energy was further triggered, Jiyu-Kennett (1997, pp. 144-146) realized the difference between observing mind and observed memories, which presented her a chance to observe ideas (memories), their beginning and end, which she described in the Buddhist language as awakening. 


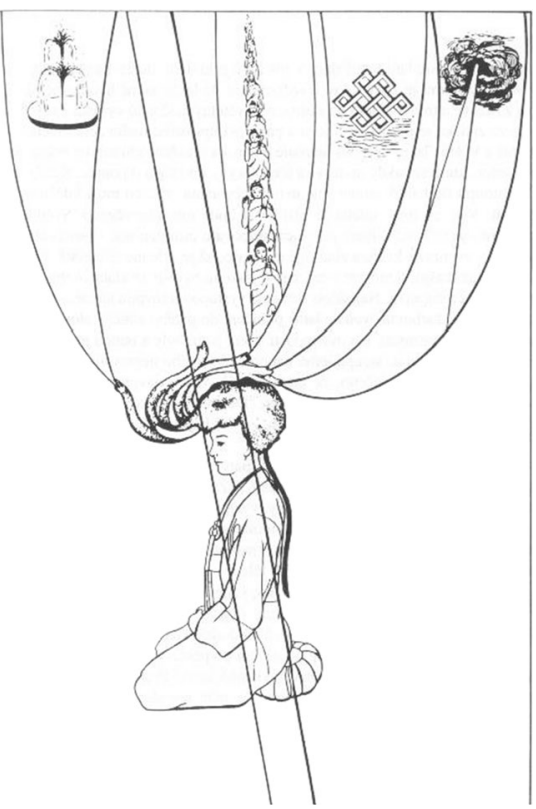

Fully developed chakra energies in Jiyu-Kennett. She was awakened in the column perpendicular to her body

We can see meditation practice with awakening of energies such as chakras or kundalini also in other mystical traditions.

For example, in Taoist text Tchaj-I Ťin-chua Cung- $\check{C}$ that Wilhelm translated (Jung and Wilhelm 2004, pp. 57-65) are chakras, and one of them corresponds to the Manipura chakra and the other correlates to Sahasrara chakra in Yoga. The first representation is explained in the Taoist text by the comment that it is 'rebirth in the space of energy'-therefore activation of the first chakra. The second representation is explained as 'awakening of the spiritual body to start independent existence.' There is also a different name of this representation'Golden Flower.' Looking at a depiction of the 'Golden Flower', we can certainly assume that this is beyond the body - a transcendent form of existence.
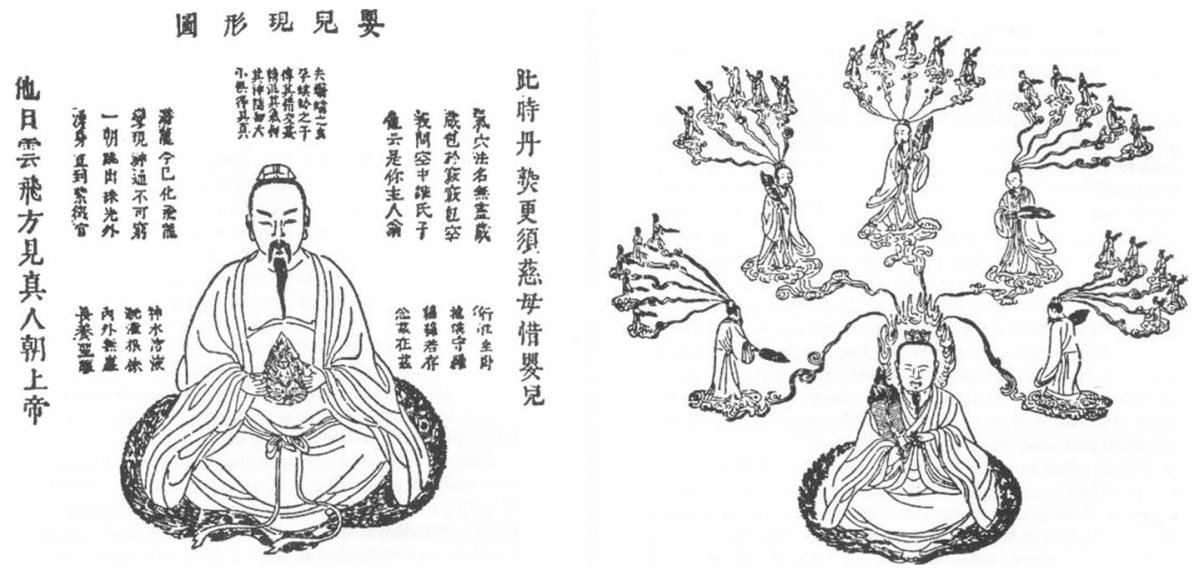

Awakening chakra energies in Taoist spiritual practice 
We believe that a principle similar to the above-mentioned spiritual traditions should also be valid for Christian mysticism. This means that the awakening of the kundalini and chakra energies is a condition for expanding awareness and insight into being; this is defined as the unity of the soul with God (lat. unio.) in the Christian religion. As a result of dualism of the soul and body in the Western Christian tradition, physiology of the body has not received as much attention in the contemplative life as it has the Eastern tradition (in orthodox Hesychast tradition, we find reference of hidden energies and breathing during prayers). Partially in the Western Christian tradition, we can find focus on bodily posture, rhythmical breathing in Ignatius' Spiritual Exercises or Gregorian chant. Despite this, we still find mentions of aura around the saints in the Western Christian iconography; this aura could represent Sahasrara in the yoga tradition. We can also find an aura in St. Teresa of Ávila icons.

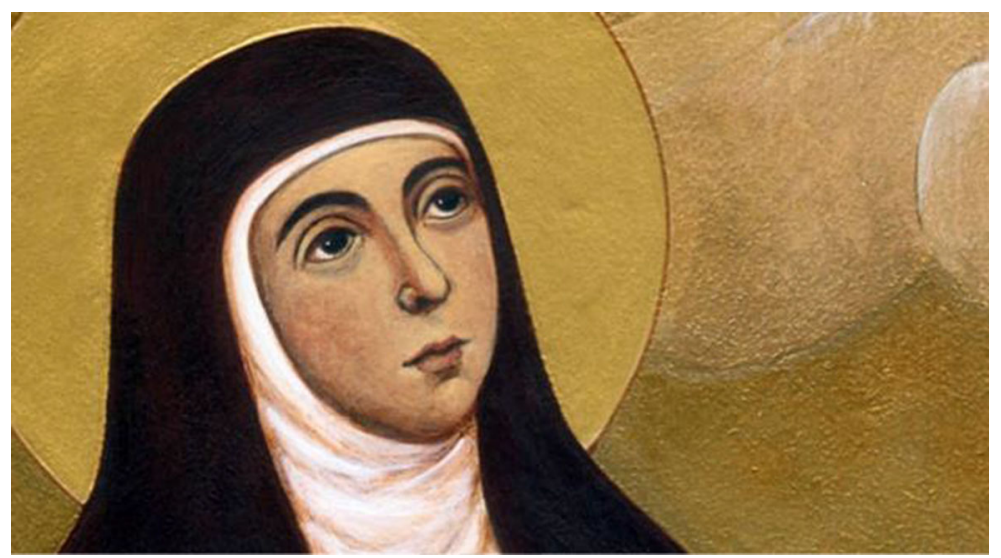

Saint Teresa of Ávila with golden aura around the head - this resembles the Sahasrara chakra

Beside showing an aura in St. Teresa of Ávila icons, it is especially notable in her descriptions of steps in prayer where she speaks of 'streams of milk,' 'light,' and similar phenomena that are remarkably similar to the energy system of the chakras. If we set aside Teresa's descriptions of mystical experiences that depend on language, culture, religion, and era, ${ }^{5}$ then the very energy system of chakras and kundalini could be valuable for us for a better understanding of Christian mysticism and the phenomenon of mystical death in St. Teresa of Ávila.

\footnotetext{
${ }^{5}$ Of course, this approach, which is based on examining subtle energies, does bring certain reduction of mysticism. However, with this reduction also come some positives, as it introduces a chance to study mysticism more objectively (developed subtle energies are visible to the naked eye) and stay in the field of science (K. Korotkov made tools based on electro-photonic imaging specially for express-assessment of the energetic state of a person including biofield of man and chakras). If somebody develops their energy potential (subtle body), then we expect some special mystical states too. However, the ideal scenario comes when people who study these states develop such energies themselves, because then they can compare this state also to other traditions. Thus, the human body, with its energy potential, turns mysticism into a phenomenon that can be studied universally and objectively. Here we can also note Buddha's statement, in which he sees the human body as a way for freeing: 'Within this body, six feet tall, endowed with perception and cognition, is contained the world, the origin of the world, and the end of the world, and the path leading towards the end of the world' (Grimm 1973, 90). However, if we decided to study mysticism purely through language and symbols (or possibly through various spiritual visions or revelations), then we would try to 'compare the incomparable' and would get stuck in never-ending speculations and permanent uncertainty. We would basically not be able to understand mysticism, and especially its inter-religious scope.
} 


\section{About Mystical Death in Teresa's Work The Life of Teresa of Jesus}

Though in her autobiography The Life of Teresa Jesus St. Teresa of Ávila does not speak about mystical death, we can still find certain life turning points that can be described as 'mystical death.' There are basically two turning points, and the second one was extremely intense. St. Teresa of Ávila found herself on the boundary between death and life. The first curious case happened during her stay in the Augustinian Convent. At the age of 16, Teresa was sent to the convent by her father, to study. At first she was not contented with her life in the convent, but gradually found peace and felt even better than at home. However, she still was not determined to become a nun (Teresa of Ávila 1904, p. 41): 'These good thoughts about being a nun came to me from time to time but they soon left me and I could not persuade myself to become one.' At that time, Teresa of Ávila was considering a nun's life and ordinary life. She later became ill and interpreted her situation as given by God, as position that most matched her soul (Teresa of Ávila 1904, p. 41): 'At this time, though I was not careless about my own improvement, the Lord became more desirous of preparing me for the state of life which was best for me. He sent me a serious illness, which forced me to return to my father's house. When I got better, they took me to see my sister, who was living in a village.' Teresa was still thinking about life in convent and ordinary life in marriage. In the period of decision-making, she said (Teresa of Ávila 1904, p. 42): 'I was subject to fainting-fits, attended with fever,- - for my health was always weak.'

This first significant breakpoint in Teresa's life, which was filled with inner struggles and decisions that were probably cause for her serious illnesses, could probably be evaluated as mental, psycho-spiritual crises. Teresa finally decided to leave for convent and live the life of a nun, but she also needed to go through inner cleansing that had a relation with her illness, fevers, and state of unconsciousness. It seems that in Teresa's case, something similar was happening, something like gradual submersion into spiritual life. Teresa (Teresa of Ávila 1904, p. 45), for example, says that she was barely 20 and already had been experiencing a prayer of silence and unity, but she hardly ever knew what was happening. It seems she experienced these mystical occurrences, even though they were short and she did not understand them then, even before she came to the Carmelite Convent for the second time. Yet, we can speak about signs of her already gradually submerging into spiritual life. This period of her spiritual life is similar to the so-called mystical death, but she remained, it seems, yet unfinished.

The second phase, which was even more important and significant, came into the spiritual life of St. Teresa of Ávila after she had come to the Carmelite Convent of Incarnation in Ávila. It was in 1535, and she was 20 then. She was unable to come earlier because it was the age of 20 that was considered to be adulthood in women in Spain at that time, and Teresa went there against her father's will. Her father, having lost his wife, wanted her to look after the household. However, she felt very unhappy about leaving, because she loved her father very much (Teresa of Ávila 1904, p. 42): 'I remember - and I really believe this is true - that when I left my father's house my distress was so great that I do not think it will be greater when I die. It seemed to me as if every bone in my body were being wrenched asunder.' The internal affliction that Teresa speaks about probably relates to her disconnecting from natural life bounds, such as family. In relation with family, the closest people, the 'very self of the person' is formed, so we can also suppose that her doing so also meant she was struggling to 
abandon the 'self.' Because being human involves a unity of body and soul, Teresa's mental suffering was also accompanied by her physical suffering. Teresa spoke about her bad health being a result of the change of lifestyle and diet, but it seems to be more probable that it was a result of the above-mentioned spiritual crises, or more precisely the process of detaching from human relationships and the world. Later, when Teresa finds her internal balance, she does not mention illnesses at all. She even noticed that the less careful she was about her health, the healthier she was. Her sickness, however, as she describes it, was very serious (Teresa of Ávila 1904, p. 44): 'My fainting fits began to increase in number and I suffered so much from heart trouble that everyone who saw me was alarmed. ... My condition became so serious - for I hardly ever seemed to be fully conscious, and sometimes I lost consciousness altogether - that my father made great efforts to find me a cure.' It was due to her health problems that she had to leave the convent. She was even treated by a woman herbalist, but she still took a turn for the worse. Her illness advanced so much that between August 15 and August 18 in 1537 she fell unconscious and was thought to have died, so they even prepared her grave (Teresa of Ávila 1904, p. 50): 'That night I had a seizure, which left me unconscious for nearly four days. During that time they gave me the Sacrament of Unction, and from hour to hour, from moment to moment, thought I was dying ... For a day and a half there was an open grave in my convent, where they were awaiting my body, and in one of the monasteries of our Order, some way from here, they had performed the rites for the dead.' They thought Teresa was dead and wanted to bury her, but her father refused to do so, claiming she was still alive. Four days later, she finally became conscious. F. Ribera, the first biographer of the saint (Terezie od Ježíše 2006, p. 35), stated that the moment St. Teresa regained her consciousness she asked: 'That very night my sickness became so acute, that for about four days I remained insensible. They administered the Sacrament of the last Anointing, and every hour, or rather every moment, thought I was dying... For a day-and-a-half the grave was open in my monastery, waiting for my body, and the Friars of our Order, in a house at some distance from this place, performed funeral solemnities.'

The second case from Teresa's life clearly proves that she was balancing between life and death, and her experiences of her 4-day coma had a transcendent nature. For those who saw Teresa, she appeared to be dead, yet she was going through very intense experiences that were exceeding time and space. Seeing this from the modern point of view, we could say that Teresa went through the so-called near-death experience, or NDE, when she survived coma in 1537 . We can generally say that NDE has a strong transforming effect on a human. Referring to Kenneth Ring, Ma'súmian (1995, p. 155) claims: 'people experiencing NDE value life and love higher and also care more about other people, while their effort to gain prestige and material possession weakens. Most people who have experienced NDE also say that they have developed a sense of spiritual life, in some cases they also look for a deeper understanding of the principal meaning of life.' It is quite natural to suppose that Teresa's spiritual life was changed after this experience, at least in the fact that she felt to be detached from everything and did not have to fight with the old, earthly relations and God.

Even though experience with NDE shows some similarities, it cannot be fully identified with the phenomenon of mystical death. The chief difference is that NDE is usually a result of a sudden medical condition, for example, heart attack. Mystical death, however, is generated progressively, through meditation and gradual 
development of subtle energies. Furthermore, once NDE occurs, it usually does not happen again, unlike mystical death, which can be repeated and even intensified until one reaches a rather stable transcendent state. We can speak of a permanent state of transcendence (we could call it a 'permanent mystical death') in Teresa of Ávila's mysticism. She says in the seventh mansion of her Interior Castle (Teresa of Ávila 1921, p. 121): ' . . in the spiritual marriage with our Lord, the soul always remains in its centre with its God.'

It seems then that Teresa of Ávila's mysticism is a combination of NDE and a spiritual way of life that she was very keen to lead (prayers and meditations). However, the NDE triggered her to submerge in spiritual life even more. Her NDE in 1537 definitely had a great effect on her psychological and physical conditions, merely by staying in her fresh memory. Despite this, she commented critically her own spiritual state after 1540; this could have a psychological explanation — her healing and regained happiness in life.

\section{The Problem of Mystical Death in Teresa's Work The Interior Castle or The Mansions}

In her book The Interior Castle or The Mansions, which she wrote in 1577, Teresa offers a systematic explanation of her mysticism. The outline of her work is not set out in a chronological sequence, as in her work The Life of Teresa of Jesus, but on logical (indirectly chronological), systematic progression of grades of prayer, or grades of perfection of The Interior Castle or The Mansions. From the aspect of mystical death, the description of the fifth mansion is the crucial one, and shows signs of the phenomenon that we explore. We will concentrate on this phenomenon, but we will also briefly discuss all of the degrees (mansions). We are basing this on the assumption, already explained in the 'Comparison of the Chakra System in Various Mystical Traditions' section, namely that Teresa's degrees of prayer (chambers), especially the higher stages (fourth to seventh), correspond to chakras in yoga and other Eastern spiritual traditions. We suppose that these subtle energies (chakras) influenced the phenomenon of mystical death in Teresa of Ávila's spirituality too.

Teresa of Ávila was ordered to write about her experience of prayer. When she was thinking about her approach, she had a vision of a crystal globe with seven mansions, which she adapted to write about her progressive spiritual life (Teresa of Ávila 1921, p. 17): 'I thought of the soul as resembling a castle, formed of a single diamond or a very transparent crystal, and containing many rooms, just as in heaven there are many mansions.'

The first three mansions represent some kind of pre-stages of deeper mystical experiences and the mystical stage of purificatio. As Teresa writes, these are easily accessible for the negative characters of humans, and she pictures them as frogs, lizards, and venomous snakes. According to Vietri's summary (2007, p. 75), in the first three mansions, the spiritual life becomes more important, and there is a gradual shift in priorities - new attitudes and values that present the building blocks upon which Teresa builds her treatises concerning ultimate union with God.

The fourth mansion represents a mystical stage of illuminatio. This is the place where spiritual transformation starts. Teresa says (Teresa of Ávila 1921, p. 39): 
'Henceforth they begin to be supernatural and it will be most difficult to speak clearly about them ...' Really, the fourth degree is in all religions supposed to be the center, the heart of spiritual existence. Teresa of Ávila surprisingly adds this (Teresa of Ávila 1921, p. 44): 'This joy does not appear to me to originate in the heart, but in some more interior part and, as it were, in the depths of our being. I think this must be the centre of the soul, as I have since learnt and will explain later on.' In this center of the soul, Teresa says it is very difficult to distinguish where the soul ends and God starts. She speaks of this poetically (Teresa of Ávila 1921, p. 44): '...the dilation begun by the celestial waters in the depths of our being. They appear to dilate and enlarge us internally, ...' Teresa speaks here about expanding the heart, which resembles spiritual techniques, to expand consciousness. It is not important if we speak about expanding the heart or expanding consciousness; it is the expanding itself that is required for opening of the self for the spiritual and transcendent. What is remarkable with Teresa is also her frequently mentioned element of water (inner light in consciousness in Teresa's approach can be seen as 'celestial waters'), which symbolizes the life-giving flow of subtle forms of energy coming from the very depth, beyond the borders of the body. Teresa's description of the nice smell and warmth that even penetrate the body (Teresa of Ávila 1921, p. 44) is similar to development of the subtle, or chakra energies: 'Although the spirit neither sees the flame nor knows where it is, yet it is penetrated by the warmth and scented fumes which are sometimes perceived even by the body.' We agree with Tsoukatos (2011, p. 153), who claims that the symbol of water in Teresa's spiritual learning means a vehicle for prayer and, we could add, also higher mystical degrees. In our study, we suppose that these energies, metaphorically expressed as 'heavenly water', warmth, or pleasant smell, served literally as a 'vehicle' that carried Teresa to the highest mystical levels.

Change, or deeper spiritual knowledge, comes with the fourth mansion, but the transformation only happens in the fifth mansion (fifth, sixth, and seventh mansions represent gradual mystical stages of unio). Teresa uses in her description of spiritual change the ancient idea, which she might have seen, of transformation from a caterpillar into a white butterfly. Teresa interprets this transformation in these words (Teresa of Ávila 1921, p. 58): "Now let us see what becomes of the "silkworm," for all I have been saying leads to this. As soon as, by means of this prayer, the soul has become entirely dead to the world, it comes forth like a lovely little white butterfly!' A butterfly represented the soul and reflection of internal transformation in the old cultures. This change is, according to Teresa, quite fast. The caterpillar dies and starts a new life in the form of a white butterfly, which can be transferred to Paul's idea of the death of an old human and birth of a new one. Eileen Mary (1983, p. 37) similarly claims that in this mansion, it is a favorite image - the butterfly, a symbol of the Resurrection, which lives because the silkworm has died in its cocoon. It means the death of the old so that the new may grow. Through the symbol of change from the silkworm to the butterfly, Teresa emphasizes destroying of the ego in the fifth mansion. Ego is diminished and the importance of self and petty worries is reduced. One no longer feels the need to control events and has no trouble controlling his impulses. Teresa further explains the nature of this mystical death (Teresa of Ávila 1921, p. 54): 'This is a delicious death, for the soul is deprived of the faculties it exercised while in the body: delicious because, (although not really the case), it seems to have left its mortal covering to abide more entirely in God. So completely does this take place, that I know not whether the body 
retains sufficient life to continue breathing.' In Teresa's opinion, the fifth mansion is the place where a simple union with God happens. Even though in the fifth mansion Teresa does not mention any 'light,' 'heavenly water,' or 'warmth' - nothing that could resemble subtle (chakra) energies - in the following, especially the seventh mansion, she speaks explicitly about them. If we then linked development of these energiesstarting with the fourth mansion and finishing with the seventh one-we could expect their effect in the fifth mansion too, the mansion in which Teresa experienced her mystical death (symbolic transformation from caterpillar to butterfly).

But in the work The Way of Perfection, Teresa metaphorically speaks about the element of water (living water), which penetrated her from the inside, from the core of the soul, and in a certain stage caused her near death. Teresa says (Teresa of Jesus 1919, p. 115): 'O Lord! is any one plunged so deeply into this living water as to die of it? Could such a thing happen? Yes. This love and desire of God may increase until nature can bear it no longer and men have perished from this cause. ${ }^{6}$ Reading this statement, we could deduce that the subtle (chakra) energies, expressed also as 'living water,' constituted an important means for Teresa to experience mystical death; therefore, this is why they should also be in the fifth mansion of her Interior Castle.

The preparation for spiritual marriage starts in the sixth mansion, which is also a place where, often, states of ecstasy come with visions, inner voices, and similar occurrences. Teresa speaks about visions of new countries yet to be seen. These experiences are congruent with states in different mysticisms, characterized by deep submerging into unconscious states and communication with spirits, gods, or travel beyond our time and dimensions. Mary (1983, p. 40) describes Teresa's mystical experiences under four headings: (1) corporeal, imaginary, and intellectual locutions; (2) ecstasies; (3) intellectual visions; (4) imaginary visions. This stage that describes many new spiritual experiences is, according to Vietri (2007, p. 83), progressive union with God.

In the seventh mansion, however, Teresa (Teresa of Ávila 1921, p. 121) says that these states cease and peace with spiritual stabilization comes along with perfect unity with God, which she explains in these words: 'But spiritual marriage is like rain falling from heaven into a river or stream, becoming one and the same liquid, so that the river and rain water cannot be divided; or it resembles a streamlet flowing into the ocean, which cannot afterwards be disunited from it. This marriage may also be likened to a room into which a bright light enters through two windows - though divided when it enters, the light becomes one and the same.' This unity is full and absolute; Teresa says that difference can be seen only in the phase of preparation for spiritual marriage, when the soul is still detached from the Bridegroom. This spiritual development incorporates complete mystical way: a process of purification, illumination, also a phenomenon of mystical death (transcendence of the 'ego') and unity with God. In the seventh mansion, Teresa (Teresa of Ávila 1921, p. 121) offers a lively description of 'spouting water, milk-like rays' that flood the body and even swallow it up: 'For from the bosom of the Divinity, where God seems ever to hold this soul fast clasped, issue streams of

\footnotetext{
${ }^{6}$ This citation indicates that the there is a fine line between mystical death and real death. Unlike in the case of NDE, this transcendent state is controllable. Jiyu-Kennett (1997, pp. 223-224) speaks on this: 'I witnessed myself that the ability to die sitting down or standing up, which transcends equally well a peasant or a philosopher, can be achieved through meditation and peaceful contemplation.'
} 
milk, which solace the servants of the castle. I think He wishes them to share, in some way, the riches the soul enjoys; therefore from the flowing river in which the little streamlet is swallowed up, some drops of water flow every now and then to sustain the bodily powers, the servants of the bride and Bridegroom.' This metaphorical description of a spouting water spring is very similar to Jiyu-Kennett's drawing of developed chakra energies (see the picture in the 'Comparison of the Chakra System in Various Mystical Traditions' section). This is the reason why we believe that Teresa's descriptions correspond to subtle energies (kundalini and chakra) and that they played an important part, starting with her early mystical experience in the fourth mansion, through her mystical death in the fifth mansion and finishing with the great finale (unio) in the seventh mansion.

\section{Conclusions}

We studied the phenomenon of mystical death in Teresa of Ávila's spirituality through her biography and especially through her mystical masterpiece called Interior Castle. In her life, there were several important moments, but we see the breaking point in her experience with close death in 1537 . We believe that this experience greatly influenced her further spiritual development. Firstly, it was the very experience of close death and secondly her lively memory of this occasion that could trigger further transformation. We also used her work Interior Castle; in this, she describes her internal transformation taking as an example caterpillar's transformation to butterfly. In this work and especially in the fourth and seventh mansions, she metaphorically describes 'living water, light, warmth, and pleasant smells'; we believe she actually describes subtle (chakra) energies that are explicitly found in yoga and other Eastern spiritualities. These energies work as a 'vehicle' that can carry human's consciousness outside a human body structure. We based our assumption on the fact that these energies worked also in the fifth mansion because their existence started in the fourth mansion and developed fully in the seventh mansion; they were furthermore indicated also in the work The Way of Perfection. Both of these sources, NDE and subtle energies, combine so they could accelerate Teresa's spiritual life to reach a permanent state of transcendence in unio. Even though the phenomenon of mystical death cannot be precisely specified chronologically (whether we speak of her NDE in 1537 or outer occurrences), we need to take it for granted as it was a necessary condition for Teresa to reach the mystical completion of transcendence in unio. An understanding of mystical death is therefore important for understanding a deep transformation (from selfcenteredness to other-centeredness) of Teresa of Ávila's mysticism. At the same time, this understanding provides a key for unlocking a major theme of her mystical works.

If we compare the way to mystical death in Teresa of Ávila and mystical death in another, especially in Eastern spiritual traditions, then we can see considerable relations (Küng and von Stietencron 1997, p. 68). For example, Zen-Buddhist Jiyu-Kennett (1997, pp. 75-115), who we have already mentioned several times, impressively described and depicted the process of expansion of these interior energies: that the fifth center of spiritual energy - throat — drew her to a short death, mystical death. In 
both of these cases, the internal energies, perceived as beams of light and taking the form of 'milk-like beams', 'water' in normal conscious state, at a certain grade started transposition of consciousness in these mystics, freeing their consciousness of psychophysical structures. This energy, whose accompanying effect can be in increasing the body temperature (Teresa would often have fevers), is a medium for consciousness and its liberation from the body.

In Jewish mysticism, as well, the ego is an obstacle to the spiritual growth of a human. Lancaster (2000, p. 132) claims that the mystic way is trying to cross the world of 'somethingness', which is psychologically controlled by our ego, and approach the nothingness. Only this way can he truly open himself up for God's wisdom.

In Islamic mysticism, more precisely in Sufism, we speak of the lower spiritual ego and higher spiritual ego. Reaching unity with God is therefore conditioned by the higher spiritual ego winning over the lower, false ego. Hazrat Inayat Khan (Witteveen 1998, p. 139) explains that ego is the principal part of our mind, just like idea, logic, memory, or the power of will. It starts its existence when the soul, on its way, gains the two tools - mind and body. According to Khan, our mind and body reflect the element of universal consciousness, which in reality is universal spirit creating individual souls from this part of consciousness. According to him, we believe we are represented by our bodies and minds. This is the basic illusion and cause of all of life's tragedies. This identification creates the false ego, and it is this illusion that we must overcome to find the real nature of our mind, our new ego united with the universal spirit.

These few examples imply that there are surprising similarities between the mystical death of Teresa of Ávila (including development of the subtle energies and mystical unity) and other spiritual traditions. These similarities should be studied intensively. It is encouraging that the history of spirituality offers such approaches. For example, Sarvepalli Radhakrishnan (Hajko 2008, p. 197) notes that all religions contain Sanatana Dharma, through which human beings may reach transcendent consciousness. Sanatana Dharma is a mystical pole of all religions, and mystics in various religions have spoken a universal, mystical language. Through Sanatana Dharma, Radhakrishnan explains, it is possible to reach even world unity and keep religious and cultural diversity at the same time. The life and writings of Teresa of Ávila are an instance of Sanatana Dharma, as a theory of human beings reach for transcendent consciousness.

To conclude, concerning the phenomenon of mystical death (including the idea of subtle energies and mystical unity), we can state that similarities found in various religious and spiritual traditions can be very significant for understanding human being and hir further spiritual development (Gálik and Gáliková Tolnaiová 2015b).

Open Access This article is licensed under a Creative Commons Attribution 4.0 International License, which permits use, sharing, adaptation, distribution and reproduction in any medium or format, as long as you give appropriate credit to the original author(s) and the source, provide a link to the Creative Commons licence, and indicate if changes were made. The images or other third party material in this article are included in the article's Creative Commons licence, unless indicated otherwise in a credit line to the material. If material is not included in the article's Creative Commons licence and your intended use is not permitted by statutory regulation or exceeds the permitted use, you will need to obtain permission directly from the copyright holder. To view a copy of this licence, visit http://creativecommons.org/licenses/by/4.0/. 


\section{References}

Antalík, D. (2005). Jak srovnávat nesrovnatelné. Strategie mezináboženské komparace. Praha: Oikoymenh.

Bialas, M. (1990). The mysticism of the passion in St. Paul of the Cross (1694-1775). San Francisco: Ignatius Press.

Davy, M.-M. (2000). Encyklopedie mystiky I. (Encyclopédie des mystiques). Praha: Argo.

Eliade, M. (1997). Dejiny náboženských predstáv a idei II. Od Gautamu Buddhu po vitazstvo krest'anstva (Histoire des croyances et des idées religieuses II. De Gautama Bouddha au triomphe du christianisme). Bratislava: Agora.

Gálik, S., \& Cenká, R. (2013). Twilight of christianity in tele-view of the world: from Homo religiosus to Homo videns. European Journal of Science and Theology, 9(5), 225-236.

Gálik, S., \& Gáliková Tolnaiová, S. (2015a). Influence of internet on the cognitive abilities of man. Phenomenological and hermeneutical approach. Communication Today, 6(1), 4-15.

Gálik, S., \& Gáliková Tolnaiová, S. (2015b). A comparison of spiritual traditions in the context of the universality of mysticism. Spirituality Studies, 1(1), 97-112.

Grimm, G. (1973). The doctrine of the Buddha, the religion of reason and meditation. Delhi: Motilal Banarsidass Publisher.

Hajko, D. (2008). Úvod do indickej filozofie. Hodnoty a východiská. Bratislava: H\&H.

Jan od Kříže. (1995). Temná noc (Noche oscura). Kostelní Vydři: Karmelitánske nakladatelství.

Jiyu-Kennett. (1997). Jak pěstovat lotosový květ aneb jak se zenový buddhista připravuje na smrt. (How to Grow a Lotus Blossom or How a Zen Buddhist Prepares for Death). Bratislava: CAD Press.

John of the Cross. (1952). Ascent of Mount Carmel. Westmonasterii.

Jung, C. G., \& Wilhelm, R. (2004). Tajemství zlatého květu. Čínská kniha života (Das Geheimnis der Goldenen Blüte - Ein chinesisches Lebensbuch). Praha: Vyšehrad.

Krišnamurti, D., \& Bohm, D. (1992). O budoucnosti lidstva. Rozhovory (about the future of humankind. Talks). Praha: Pragma.

Kumar, R., \& Larsen Kumar, J. (2006). Kundalíni aneb kniha o životě a smrti (the Kundalini book of living and dying). Praha: Eminent.

Küng, H., \& von Stietencron, H. (1997). Křest'anství a hinduismus (Christentum und Weltreligionen Hinduismus). Praha: Vyšehrad.

Lancaster, B. (2000). Judaizmus (the elements of Judaism). Bratislava: Ikar.

Larkin, E. E. (1967). The three spiritual ways. In New Catholic Encyclopedia. (Vol. XIV, 835-836). San Francisco: McGraw-Hill. Available in: http://carmelnet.org/larkin/larkin092.pdf.

Mary, E. (1983). Pilgrimage and possession: Conversion in the writing of St. Teresa and St. John of the Cross. Oxford: Convent of Incarnation.

Ma súmián, F. (1995). Život po smrti (Life after death). Brno: Jota. Available in: http://www.slgpress.co. uk/CMS/FREE_PDFs/E_FP086.pdf.

Ricoeur, P. (1980). Essays on biblical interpretation. In Religion-Online. Available in: http://media.sabda. org/alkitab-2/Religion-Online.org\%20Books/Ricoeur,\%20Paul\%20-\%20Essays\%20on\%20Biblical\%20 Interpretation.Pdf.

Stevens, A. (1994). Jung. Oxford University Press.

Sudbrack, J. (1995). Mystika (Mystik). Kostelní Vydř́: Karmelitánske nakladatelství.

Sudbrack, J. (1998). Religiöse Erfahrung und menschliche Psyche: zu Grenzfragen von Religion und Psychologie, von Heiligkeit und Krankheit, von Gott und Satan. Mainz: Matthias-Grünewald.

Teresa of Ávila. (1904). The Life of St. Teresa of Jesus, of the Order of Our Lady of Carmel. London: Thomas Baker. https://www.catholicspiritualdirection.org/lifeofteresa.pdf

Teresa of Ávila. (1921). The interior castle or the mansions. London: Thomas Baker.

Teresa of Jesus (1919). The way of perfection. London: Thomas Baker. http://staugustinechapel. org/Library/books_pdf/THE_WAY_OF_PERFECTION_TeresaAvila_OCR_CK.pdf.

Terezie od Ježíše, S. (2006). Život (the life). Kostelní Vydří: Karmelitánske nakladatelství.

Treatise on mystical death (Studies of St. Paul of the Cross). (n.d.). The passionists of holy cross province. Available in: https://www.yumpu.com/en/document/view/47280069/treatise-on-mystical-death.pdf.

Tsoukatos, E. G. (2011). Finding God in all things: Teresa of Ávila's use of the familiar. [Unpublished doctoral thesis.] Georgetown University, Washington D.C. https://repository.library.georgetown. edu/bitstream/handle/10822/558179/Tsoukatos_georgetown_0076D_11409.pdf?sequence=1.

Vietri. C. D. (2007). The journey to God through the spirituality of Teresa of Ávila (1515-1582). [Unpublished master's thesis]. University of South Africa. https:/uir.unisa.ac.za/bitstream/handle/10500 /1690/dissertation.pdf?sequence=1\%CB\%83. 
Wehr, G. (1999). Mistr Eckhart (Meister Eckhardt). Olomouc: Votobia.

Wehr, G. (2010). Meister Eckhart. Texte und Kommentar von Gerhard Wehr. Wiesbaden: Marixverlag $\mathrm{GmbH}$.

Witteveen, H. J. (1998). Univerzální súfismus (Universal Sufism). Praha: Alternativa.

Zarrabi-Zadeh, S. (2008). Defining mysticism, A survey of main definitions. Transcendent Philosophy, 9, 7792.

Publisher's Note Springer Nature remains neutral with regard to jurisdictional claims in published maps and institutional affiliations.

\section{Affiliations}

\section{Slavomír Gálik ${ }^{1}$ · Sabína Gáliková Tolnaiová ${ }^{1}$ • Arkadiusz Modrzejewski ${ }^{2}$}

Sabína Gáliková Tolnaiová

sgalikovatolnaiova@gmail.com

Arkadiusz Modrzejewski

modrzejewski@ug.edu.pl

1 Faculty of Mass Media Communication, University of Ss. Cyril and Methodius in Trnava, 917 01 Trnava, Slovakia

2 Department of Political Science, University of Gdańsk, Baźyńskiego 4, 80-952 Gdańsk, Poland 